\title{
2 Designing Conditions for the Social
}

\section{Anders Emilson}

In recent years, social innovation has been seen as a way to tackle climate change, aging populations, and social exclusion. The U.S. government (SICP 2012), the European Union (Hubert 2011), the Young Foundation, and the Rockefeller Foundation acknowledge social innovation as important. Nicholls and Murdock (2012, 1-2) consider social innovation to be a "sixth wave" of macro-innovation following more technology-based predecessors: the industrial revolution; steam and railways; steel, electricity, and heavy engineering; oil, automobiles, and mass production; and information and telecommunications. Design as a discipline emerged in parallel to these earlier waves of macro-innovations as a response to the need of adapting technological artifacts to human needs, behaviors and measures. Today, design is also one of the creative disciplines that are active in social innovation. In the next two chapters, we look into cases where design methods are applied to create social innovation and into the emerging design discipline known as design for social innovation, sometimes referred to as social design. Designers are not alone in this field; social innovations can be created by many methods used by such diverse actors as social entrepreneurs, public servants, commercial companies, or activists. Another characteristic of social innovation that will be emphasized is that it often emerges from collaborations between actors from different sectors and disciplines.

One might ask what design methods have to offer in these constellations of diverse actors. Before looking for an answer, let us acknowledge the fact that design has a long history of being involved in shaping the societies we live in. In Europe, the modern movement of the early twentieth century (most strongly symbolized by the German Bauhaus School, with its roots in the British Arts and Crafts movement and social democracy) strove to improve people's living conditions and to build an equal and peaceful world through the use of mass production and a new modernistic design language. In Sweden, designers and architects were involved in articulating the modern welfare state through the means of urban planning, architecture, furniture, and the design of everyday objects according to modernist principles. We all know that many of these well-intentioned designs can be considered failures, most explicitly exemplified with the demolition of the infamous Pruitt-Igoe housing project in St. Louis in 1972. 
Pruitt-Igoe, completed in 1955, consisted of 33 rectangular eleven-story apartment buildings. Its design was based on the modernist International Style invented by Le Corbusier, Walter Gropius, and others in the 1920s and the 1930s. In Sweden, about a million apartments were built between 1965 and 1974 following these modernist design principles. The housing situation in Sweden was similar to that in St. Louis: there was a need to replace overcrowded slums with new housing. But soon, as in Pruitt-Igoe, many (though not all) of these new projects became associated with poverty, segregation, and crime. In 1977 the architectural historian Charles Jenks argued that the demolition of Pruitt-Igoe symbolized the failure and death of modernistic architecture (Bristol 1991, 163). Others argued that not all the blame should be put on architectural design alone, and that social and economic factors should be considered. Katharine Bristol claimed that the exaggerated focus on the designers' responsibility in Pruitt-Igoe had diverted attention from the "institutional or structural sources of public housing problems" and had legitimized the architecture profession by "implying that deeply embedded social problems are caused, and therefore solved, by architectural design" (ibid.).

The real lesson to be learned from Pruitt-Igoe, thus, is not about formal design of an object, but that complex societal challenges call for the kind of participatory and crossdisciplinary work that is discussed in the following two chapters. On the other hand, one cannot ignore the fact that problems in many of these modernistic housing areas remain today. At the time of this writing, there have just been week-long riots in several housing areas in various parts of Stockholm. A few years ago there were riots in Malmö. Some of our collaborators live and work in modernistic housing areas, and some of our work targets present-day challenges in these areas-challenges such as social exclusion, unemployment, and the need for renovation. The question, of course, is "Will we make the same mistakes as the well-intentioned designers and social engineers before us?"

A less well known successor to the socially engaged and "democratic design" characterizing the modernist tradition is the Scandinavian Participatory Design tradition that began in the 1970s. But, as the name indicates, this was different than some idealistic designers and architects that considered themselves experts on how people should live and what products they should consume. Instead of designing for people, designers within the participatory design tradition involved the people concerned and designed with them, starting from their own experiences and desires. Participatory design originates from the social, political, and civil rights movements of the 1960s and the 1970s, when people "demanded an increased say in the decisions that affected many different aspects of their lives" (Robertson and Simonsen 2012, 3). Influenced by these movements, designers began to claim that "if we are to design the futures we wish to live, then those whose futures are affected must actively participate in the design process" (ibid., 5). 
This approach fits well with what Mulgan (2012a) considers to be the underlying ethic of collaboration in social innovation: to act with rather than for. Or, in the words of President José Manuel Barroso of the European Commission: "In a nutshell, social innovation is for the people and with the people." (Barroso 2011, no paging) Designing with people is part of a major shift in innovation (Chesbrough 2003; Leadbeater 2008, 2009), going from closed in-house processes to more open and collaborative ones. Murray, Caulier-Grice, and Mulgan $(2010,6)$ write that innovation itself should be open and social and "welcoming responses from anyone; involving users at every stage as well as experts, bureaucrats and professionals."

To involve and design with actors that represent different positions in society is also the basis for Malmö's Living Lab the Neighborhood, which works with participatory design and social innovation in districts in Malmö marked by social exclusion. In our practice (Björgvinsson and Hillgren 2004; Björgvinsson, Ehn, and Hillgren 2010; Hillgren, Seravalli, and Emilson 2011), we put much emphasis on building long-term relationships and on using prototyping as a way to evoke and explore possibilities and dilemmas. Our activities are based on three methodological ideas:

- to set up collaborative design processes where diverse stakeholders with complementary skills work side by side and where mutual respect and learning is supported

- to build long-term relationships and trust with stakeholders

- to perform early prototyping where possibilities are explored in real-life contexts but where potential dilemmas also are highlighted.

Social innovation often demands multiple perspectives (Murray, Caulier-Grice, and Mulgan 2010; den Ouden and Valkenburg 2011), and we collaborate with nongovernmental organizations, municipalities, and private business partners. Over the years, we have worked with associations, small media and design companies, successful ICT companies, public transport and public broadcasting companies, and municipal departments on projects such as using a mobile phone game to explore marginalized neighborhoods, street journalism by youths, and new collaborative tools for city planning. Often we establish relationships with actors separately to explore possibilities related to their respective interests and agendas, getting multiple starting points for potential projects and innovation. At the same time, we also try to see how different interests might be integrated.

Today, when "co-design" and "working with people" have become recurring mantras in both social innovation and in design, we know-through 30 years of experience in the participatory design field-that this is not always easy. Conflicting interests, values, or ways of working often threaten to cause projects to collapse, and at times projects are closed down because the different actors do not match with each other as intended. But, we will argue, this is not a reason for giving up; instead it is a reason to 
see the matching of people and the creation of constellations as a kind of prototyping process: if one match doesn't work, try another. This could be seen as designing the social conditions of the participatory process and also the core of "infrastructuring" (Björgvinsson, Ehn, and Hillgren 2010)—the building of long-term relationships and the matching of actors with complementary resources.

Concepts such as "infrastructuring," "design things," and "agonism" are both analytical and methodological, and such concepts have been central to our research. They have also been important tools in our work with the creation of social conditions"networks and relations" (Binder et al. 2011, 157)—in the design process.

By the social, we mean the interactions and relations between people who are gathered in a constellation or a design project. By conditions, we mean the creation of constellations of actors who take part in a mutual learning process guided by designers using tools such as workshops, scenarios, and prototypes. In this way, we try to explore new challenges for designers that are more about people and networks than about technology and objects. Important issues are how to create trust, how to show respect for the opinions of others, and how to facilitate mutual learning in a constellation. We also want to explore the role of the social in networks, creative processes, new business models, and new concepts such as collaborative services and collaborative consumption. At the core is dealing with people with different agendas and values. This has the consequence that the designer needs to have competence in dealing with conflicts, dilemmas, power relations, and politics. While this is nothing new for designers working with participatory design, the challenge with social innovation is the new context in which more heterogeneous actors take part, the "place" is a neighborhood rather than a workplace, and the designed artifact is more likely to be a service, a practice, or an organization than a piece of technology. Let us take a quick look at how design is being applied in the field of social innovation.

\section{The field of social innovation}

Social innovation as a field has emerged as existing structures, policies, and tools, both from the market and from the state, have proved inadequate for tackling many of today's social and societal challenges. It is a reaction to the previous dominance of technological and business aspects in innovation policy and practice. Social innovation is also a response to the complexity of present-day societal challenges, such as failing welfare systems, that affect both individuals and society as a whole; therefore, it involves heterogeneous actors across sectors and disciplines. Social innovation can be seen as an umbrella concept covering different ways-such as entrepreneurship, financing, and activism-of responding to social demands and societal challenges.

Social innovation is nothing new-individuals and organizations have always developed new solutions and concepts to address social needs. An early Swedish example of 
a social innovation, one that later became a public institution, is Barnavårdscentraler (child-care centers). They were started in 1901 by the föreningen Mjölkdroppen (2013) (Milk Drop Association) to help poor mothers to provide their children with nutritious milk. At the time, 10 percent of newborns died because breastfeeding frequency was low. In the 1940s this support for mothers and children was taken over by public child-care centers. Mjölkdroppen is an example of how a small initiative undertaken by an association develops into a public institution; it also shows the importance of civil society in developing social innovations. Other examples of public institutions that were first developed by civil society, and not by the state or the market, are fire brigades and libraries. This historical role of civil society tends to be forgotten in discussions of social innovation. Often the focus is on stronger actors in the private sector (social entrepreneurs, philanthropists) and in the public sector.

There is no single definition of social innovation, and we have experienced difficulty in communicating the concept. In trying to embrace both the breadth and the main ideas of social innovation, we turn to acknowledged researchers in the field.

Murray, Caulier-Grice, and Mulgan $(2010,3)$ describe social innovation as "new ideas (products, services and models) that simultaneously meet social needs and create new social relationships or collaborations" and as "innovations that are both good for society and enhance society's capacity to act." Phills, Deiglmeier, and Miller $(2008,39)$ emphasize that social innovation is a way to meet needs that would not be met otherwise and to create value that would otherwise not be created; thus, they define social innovation as "a novel solution to a social problem that is more effective, efficient, sustainable, or just than existing solutions and for which the value created accrues primarily to society as a whole rather than private individuals." "A social innovation," they write, "can be a product, production process, or technology (much like innovation in general), but it can also be a principle, an idea, a piece of legislation, a social movement, an intervention, or some combination of them. Indeed, many of the best recognized social innovations, such as microfinance, are combinations of a number of these elements."

According to Westley and Antadze $(2010,2)$, "social innovations involve institutional and social system change, they contribute to overall social resilience, and they demand a complex interaction between agency and intent and emergent opportunity." They define social innovation as "a complex process of introducing new products, processes or programs that profoundly change the basic routines, resource and authority flows, or beliefs of the social system in which the innovation occurs. Such successful social innovations have durability and broad impact."

As the definitions above suggest, and as Nicholls and Murdock (2012) show, social innovation exists on different levels: on an incremental level (with a focus on products and services), on an institutional level (with a focus on markets), and on a disruptive level (with a focus on politics and on system change). Hubert $(2011,43)$ frames social innovation in a process dimension (in which new forms of organization and interactions 
are developed to respond to social issues) and an outcome dimension (in which the meaning of "social" ranges from individual and groups to society as a whole). Hubert (ibid.) describes the outcome dimension through three complementary and interdependent approaches that respond to

social demands that are traditionally not addressed by the market or existing institutions and are directed towards vulnerable groups in society [Approach 1]

societal challenges in which boundaries between "social" and "economic" blurs, and which are directed towards society as a whole [Approach 2]

and

the need to reform society in the direction of a more participative arena where empowerment and learning are sources and outcomes of well-being [Approach 3].

Hubert describes the interdependence between the approaches this way: "[A]n innovation that addresses a social demand (e.g. care of the elderly) contributes to addressing a societal challenge (ageing society) and through its process dimension (e.g. the active engagement of the elderly), it contributes to reshape society in the directions of participation and empowerment." (ibid.)

Howaldt and Schwarz $(2010,21)$ write that the distinction between social and technical innovation is in the immaterial and intangible structure of social innovations: "The innovation does not occur in the medium of a technical artefact but at the level of social practice." Practice, what people really do, is also fundamental in participatory design (Robertson and Simonsen 2012). Another important characteristic of social innovation, brought up by Murray, Caulier-Grice, and Mulgan (2010, 7), is the role of stakeholder networks. Whereas in business the firm is the main agent of innovation, in social innovation the impetus is more likely to come from a wider network, "perhaps linking some commissioners in public sector, providers in social enterprises, advocates in social movements, and entrepreneurs in business" (ibid.). This insight from social innovation theory fits well with our ambition in the Living Labs of gathering a wider network of heterogeneous actors in order to explore and tackle social and societal challenges.

Our motivations for attaching ourselves to the discourse of social innovation are a belief in democratic principles and an interest in how design can play a part in exploring new possibilities to create a more sustainable, equal, and just world. To be able to reach that goal, we believe, one has to move beyond single solutions in the form of products and services that sustain business as usual or the hegemony of the establishment, and one has to address issues on both an individual level and a systemic level. We believe that the overall objective for social innovation is to reorganize society-to really affect the causes of social problems rather than merely relieve the symptoms, or, in Schulman's (2012, no paging) words, to "shake up the status quo, narrow inequalities, and set new social standards." With that ambition you will get into trouble and experience a lot of painful moments. 


\section{Design for social innovation}

As has already been mentioned, design has a history of social engagement, from William Morris (1834-1896), socialist artist, designer and leader of the Arts and Crafts movement, and Walter Gropius (1883-1969), architect and founder of the Bauhaus School, to Victor Papanek (1923-1998), designer and author of Design for the Real World: Human Ecology and Social Change. But, as Margolin and Margolin $(2002,24)$ argue, this has not led to an established "social model" for design. Instead, the "market model" has been dominant, and there has been a lack of research that might "demonstrate what a designer can contribute to human welfare" (ibid., 28). In the last ten years, however, there have been various initiatives to establish a "social model" for design, focusing on how design can contribute to society. Examples include John Thackara's Doors of Perception conferences and blog, Bruce Mau's book Massive Change and his Institute Without Boundaries, Cameron Sinclair's non-profit organization Architecture for Humanity, and Emily Pilloton's Project H Design and Design Revolution exhibition.

Also contributing to the development of this "social model" are the designers and design researchers who consider how design methods and tools could support social innovation (Jégou and Manzini 2008; DESIS 2012). Concurrently, design has been recognized as a valid tool by organizations advocating, supporting, and researching social innovation (Murray, Caulier-Grice, and Mulgan 2010; Rockefeller Foundation 2008). In 2011, the Young Foundation hired a "head of social design" to develop a new social design practice as a way to complement their current work (Kimbell 2011). At the Waterloo Institute for Social Innovation and Resilience in Ontario, Frances Westley has begun to explore the concept of social innovation labs, where inspiration from "design labs" plays an important role. Among the other contributors to the emergence of this new design field have been academic design researchers and design practitioners (the latter mainly from service-design companies and from public organizations that support design, like the Design Council in the United Kingdom, or set up their own design led innovation units, like MindLab in Denmark, La 27e Région in France, or the Helsinki design lab in Finland).

At the Politecnico di Milano, Ezio Manzini and François Jégou have led international research projects such as Emerging User Demands for Sustainable Solutions and Creative Communities for Sustainable Lifestyles (SEP 2012). Sustainability was the starting point for those projects, but subsequently the insight that sustainability is not merely a technical issue (new products) but an issue of lifestyles and behavioral changes led to the conclusion that "social innovation could be a powerful driver towards sustainability" (DESIS 2012, no paging). In their book Collaborative Services: Social Innovation and Design for Sustainability, Jégou and Manzini (2008) explicitly emphasized the concept of social innovation. Today such research is gathered under the umbrella of the DESIS (Design for Social Innovation and Sustainability) network. Design researchers from this network have identified and collected cases from what they call creative communities 
around the world. Jégou and Manzini (ibid., 30) define creative communities as "groups of people who cooperatively invent, enhance and manage innovative solutions for new ways of living." Generally, the outcomes are collaborative services that are "social services where final users are actively involved and assume the role of service co-designers and co-producers" (ibid.).

In the United Kingdom, several service design companies, among them Live Work, Engine, and ThinkPublic, began to apply design methods to social and societal challenges in the early 2000s. This occurred in parallel with support from the Design Council, which encouraged the exploration of using design in new social and public contexts through research and demonstration projects. One example was the Design Council's RED research unit, which consisted of professional designers and professionals from disciplines such as policy analysis and social sciences (Design Council 2004). Burns et al. (2006) describe the RED unit's approach, called transformation design, as based on involving heterogeneous stakeholders from the beginning through participatory design. In 2007, the RED unit became an enterprise called Participle, which, in turn, became the starting point for the design company InWithFor (which closed in 2012).

The Design Council has also initiated demonstration programs. Two such programs were Designs of the Time (Design Council 2012b) and Public Services by Design (Design Council 2008, 2012a). Furthermore, other public institutions in the United Kingdom have initiated projects involving design companies. For example, Engine (2012) has supported the Kent County Council in designing a new platform for co-creation, Live Work (2012) has created services to support hard-to-reach unemployed people, and ThinkPublic (2012, no paging) has used participatory design to engage "local residents in identifying challenges and co-designing responses to better community health and wellbeing."

In the United States too there is growing interest in design for social innovation; it is among the areas of expertise offered by the design firms IDEO, Continuum, and Frog Design. The typical approach to design for social innovation in the United States refers to projects in developing countries (Brown and Wyatt 2010). However, the DESIS Lab at the New School for Design in New York is working more in a European way; it helps local creative communities to develop collaborative services and sustainable lifestyles (DESIS Lab 2012). In the research program known as Public \& Collaborative NYC, the DESIS Lab explores what role design can play in building bridges between city government and people in the creation of social innovation (Staszowski, Brown, and Winter 2013). And Project H Design (2012) is bringing design skills into public education in a rural community.

\section{Strengths and weaknesses of design in social innovation}

One sign of how design is evolving in social innovation, Geoff Mulgan (2012b, no paging) argues, is that designers are getting "humbler about what can be achieved, and 
about what they need to learn from others" (ibid.). Mulgan was one of the first people from the field of social innovation to cite both the strengths and the weaknesses of design for social innovation. In 2009, the concept of design for social innovation was primarily associated with hype about "design thinking" and with the design-can-solveeverything attitude of many of the world's leading designers. According to Mulgan, the strengths of design for social innovation include visualization techniques, bringing novel insights, working from a user perspective, and fast prototyping. The weaknesses include lack of economical and organizational skills, inability to drive the implementation process, the cost of design consultants who often do not have a long-term commitment to a project, and the fact that designers sometimes ignore evidence and field experiences and tend to "reinvent the wheel" (Mulgan 2009). Mulgan's (2009, 2012b) critique mostly concerns design methods, but several other critical voices have been heard with regard to the ethics, the values, and the political awareness of designers working in unfamiliar contexts (Cottam 2009; Tonkinwise 2010; DiSalvo 2010; Blyth and Kimbell 2011; Schulman 2012).

\section{The big picture}

Social innovation is no longer a concern only for grassroots movements or third-sector organizations (non-governmental organizations, associations, non-profit businesses) fighting inequality or addressing global challenges such as climate change. Today, in North America and in Europe, social innovation is also a concern of governments. In the United States, President Barack Obama has created an Office of Social Innovation and Civic Participation in recognition of the idea that "the best solutions to our challenges will be found in communities across the country" (SICP 2012, no paging). Social innovation has also become a priority of the European Union's innovation policy (European Commission 2010).

According to a report titled Empowering People, Driving Change: Social Innovation in the European Union (Hubert 2011, 18), the old belief that economic growth alone could provide all the solutions to social problems has been shown to be incorrect, and social innovation can mobilize people's creativity. That report also suggests that a new form of "enabling welfare state" is emerging, and a change of attitude and the involvement of citizens, public authorities, and private organizations will be necessary if new social responses to our social challenges are to be developed.

Hubert's $(2011,35)$ description of social innovation as a "process of social interactions between individuals to reach certain outcomes" is interesting. She also refers to lessons learned from the EQUAL initiative in Portugal. That project, with its focus on increasing access to employment, is also interesting in relation to our involvement in designing an incubator for social innovation in Malmö (chapter 4) and our work on how a group of women living on public assistance can develop their activities into a 
cooperative business (chapter 3). In this chapter, I summarize some of Hubert's (2011) findings, building on the EQUAL project, that are important for an understanding of social innovation processes. These findings have much in common with the ethos of participatory design and with the theme of social conditions in participatory design:

1. Solutions must focus on the beneficiaries and be created with them, preferably by them, and never without them.

2. Focusing on the strengths of individuals and communities rather than on their weaknesses

3. Capitalizing on the diversity of ethnicities, ages, religions, gender, etc. and not just combating discrimination

4. Developing a holistic approach rather than fragmented responses to people's diverse problems

5. Reinforcing and extending partnerships rather than having each organization individually handling its services and its responsibilities

6. Collaborative working and networking as ways to stimulate social innovation

(Hubert 2011, 35)

\section{Design, politics, and some early warnings}

Co-creation and collaboration obviously are central to participatory design as well as to social innovation. They are also central to new policies (for example, the British government's "Big Society" vision) that build on citizen involvement and action, using local knowledge and social networks (Coote 2010). The goal is to "devolve power to the lowest possible level" while making "deep cuts in public spending" (ibid., 2). This policy is a huge challenge for designers. The Design Council's Dott Cornwall program has been viewed as a "Big Society laboratory" by Scott Billings (2011, 22), who also asserts that it "is not a version of Big Society where people are left to fend for themselves, but rather one where collaboration is instrumental in addressing social problems in new ways."

Even before the Big Society policy was launched, the social design firm Participle presented a vision of how to design the new welfare state in a manifesto, titled Beveridge 4.0 (Cottam 2008), that emphasizes people's aspirations and their capabilities rather than their needs and advocates involving citizens in collectively designing new responses to societal challenges. When Prime Minister David Cameron presented the Big Society policy, Hilary Cottam (2009), one of the founders of Participle, welcomed it, pointing to the similarities with Participle's agenda, but at the same time showed a political awareness by pointing to "central flaws" in Cameron's argument and criticizing his reluctance to address inequality: "Britain is one of the most unequal societies in the world. Unless we are willing to talk about and address this disparity, neither a re-imagined state nor an army of social entrepreneurs can build Cameron's big society." (Cottam 2009, no paging) Statements of this sort and a willingness to discuss the political contexts and social conditions in which designers are beginning to operate in are 
most necessary. Reflecting on the situation in the United Kingdom, where designers create new services according to government policy, Cameron Tonkinwise (2010) has brought up the need for an awareness of political and ethical matters:

Designers are already facilitating social innovations that can replace government services that David Cameron has a mandate to cut the cost of. The rhetoric, as a recent Economist article on social innovation made clear, is all about doing services better, but in ways that just happen to also save the government money and, more importantly, withdraw governments irrevocably from such services. (Tonkinwise 2010, no paging)

Simon Blyth and Lucy Kimbell (2011) have also been reflecting on the role of design in relation to the Big Society policy. Emphasizing the importance of how problems are framed and defined and how issues are made public, they argue that design should be viewed as more than problem solving. Asserting that it is important to go beyond the individual (the focus of user-centered design) and to "situate individuals within dynamic social systems" (ibid., 8), they quote the American sociologist C. Wright Mills:

[W] hen in a nation of 50 million employees, 15 million people are unemployed, that is an issue, and we may not hope to find its solution within the range of opportunities open to any one individual. The very structure of opportunities has collapsed. Both the correct statement of the problem and the range of possible solutions require us to consider the economic and political institutions of the society, and not merely the personal situation and character of a scatter of individuals. (Mills, quoted by Blyth and Kimbell 2011, 8)

Blyth and Kimbell argue that the view of the design process as a collaborative and consensual activity should be challenged, and that contestation and difference are important elements of the process-especially in public or community contexts. Sarah Schulman of the design consultancy InWithFor goes further. Drawing on her experiences in the social field, she calls for more ethical outrage in the design community and urges designers to deal with the moral dilemmas that underpin "social design" work. Those "moral dilemmas," she continues, "have informed our value set-a value set that enables us to make decisions about the projects we choose to take on, the people we choose to work with, and the solutions we co-create" (Schulman 2012, no paging).

The importance of values became evident to Schulman when she was working with a government agency whose internal co-design unit was driven more by values of "innovation" and "efficiency" than by questions regarding inequalities. Even if the methods were new, the "ends" were quite the same. "It's not that I don't believe in 'social design' methods-in starting with people, making ideas real, and iterating those ideas over time," Schulman (2012, no paging) writes, "but I believe in them insofar as they shake up the status quo, narrow inequalities, and set new social standards. The danger comes when these new design methods make social services more palatable, more attractive, and thus more difficult to challenge." 
All these reflections on social innovation and design for social innovation point to the need for more discussion of the conditions and contexts of social design work-more discussion of what to design and with whom to design, and not only of how to design. It also points to the relevance of making a distinction between what Carl DiSalvo (2010, no paging) calls design for politics (with its focus on "improving structures and mechanisms that enable governing") and political design (which focuses more on revealing and confronting power relations and on identifying "new terms and themes for contestation and new trajectories for action"). These reflections could also be seen as early warnings that, if we aren't alert, all this well-intentioned democratic design may fail and may deliver outcomes that do more harm than good-again.

\section{"Design things" and "infrastructuring": Two approaches to exploring and designing the conditions of the social?}

Among the design methods and practices that could be applied to social innovation are ethnographic studies, early and rapid prototyping, and involving diverse stakeholders in the process of co-creation. However, all these approaches must be challenged and explored further in the specific context of the present discussion. In the following two chapters, my colleagues and I will reflect on our own experiences and on the shortcomings of using design to address social and societal challenges. We will not tell success stories about creating new and life-changing public services. Instead we will offer insights, expressed through concepts such as "infrastructuring," "design things," agonism, and governance, that, we argue, could contribute to the discussion regarding social conditions in participatory design processes and to confronting many of the challenges that were touched upon earlier in the chapter. For example, we will argue that it is fruitful to consider the possibility that the concept of "design things," as developed by Ehn (2008), Björgvinsson, Ehn, and Hillgren (2010), and Binder et al. (2011), could work as a space for what DiSalvo (2010) calls "political design," and the possibility that heterogeneous stakeholders could "make decisions about the projects we choose to take on, the people we choose to work with, and the solutions we cocreate" (Schulman 2012, no paging).

Chapters 3 and 4 focus on "infrastructuring" and on the creation and the re-creation of "design things," with diverse stakeholders gathering to discuss, challenge, and reveal one another's values, interests, and agendas and to go through a process of reciprocal learning. The larger framework for both chapters is how Living Lab the Neighborhood, by setting up collaborative design processes, could address social and societal challenges and increase society's capacity to act. Here we can see interesting links between the concepts "infrastructuring" and "design things" and the conclusions reached in the final report of the Kommission för ett socialt hållbart Malmö (Commission for a Socially Sustainable Malmö): 
- the need of departing from a holistic perspective

- the importance of problem definition and that a wider circle of actors participate in defining problems and setting objectives

- the need of creating "knowledge alliances," which mean "equal collaborations between researchers and stakeholders from for example public administration, associations and trade and industry"

- the need of building an infrastructure of knowledge alliances for social innovation and urban integration (Stigendal and Östergren 2013, 128-134; translated from Swedish)

We will argue that the concepts "infrastructuring" and "design things" could contribute to the exploration of what an "infrastructure of knowledge alliances" could be. To situate our research in the local context, we will discuss infrastructuring and design things in relation to the findings in the final report of the Commission for a Socially Sustainable Malmö and in relation to research by the political scientist Tove Dannestam on "city politics" and "governance" in Malmö. Tove Dannestam and the sociologist Mikael Stigendal have made important contributions to the understanding of Malmö and will therefore be mentioned often.

In chapter 3, titled Designing in the Neighborhood, we analyze a bottom-up initiative, tell the story of a group of women who wish to start a cooperative business, and consider how the women's knowledge and skills could be transformed into services. The case in question reveals shortcomings in existing support structures (that is, in society's capacity to act) and points to the need to develop a function in society that can take a long-term responsibility for supporting initiatives that do not fit into-or that challenge-existing norms and institutions. Consequently, that chapter's main analytical concepts are "infrastructuring," "prototyping," and "friendly hacking" (Jégou et al. 2013). This is along the lines of Stigendal and Östergren's observation $(2013,48)$ that "there is a need for an infrastructure within the municipality that is able to utilize the innovation power and knowledge within civil society." (Interestingly, just such a longterm support structure was discussed in the "design thing" that was gathered to address the issue of an incubator for social innovation.)

In chapter 4, titled "Connecting with the Powerful Strangers," we analyze the initial process of developing a support structure for social innovation, the so-called incubator for social innovation-a process that was a top-down initiative by the municipality. The objective was to explore how such a support structure could function and, in Stigendal and Östergren's (2013) words, how to build an infrastructure of knowledge alliances concerned with the issue of an incubator for social innovation. That chapter's main analytical focus is on "design things" in relation to the political concepts "governance" and "agonism."

In these two cases, we have discovered potentials for new forms of work and new support structures, but we also have discovered shortcomings in existing systems and the difficulties designers will face when dealing with complex societal challenges. These 
two cases point to the need to approach social needs and societal issues from many perspectives, addressing the needs and the desires of individuals and communities and also addressing structural and systemic causes and limitations-the need to work across sectors and disciplines, from the bottom up and from the top down. In these projects, we have experienced both the joy of working with fantastic people and the agony of diving into the social and societal problems of our time.

\section{References}

Barroso, José Manuel. 2011. Europe Leading Social Innovation. Speech at Social Innovation Europe Initiative, Brussels (europa.eu/rapid/press-release_SPEECH-11-190_en.pdf).

Billings, Scott. 2011. Dott's Legacy (http://www.designcouncil.org.uk).

Binder, Thomas, Giorgio De Michelis, Pelle Ehn, Giulio Jacucci, Per Linde, and Ina Wagner. 2011. Design Things. MIT Press.

Björgvinsson, Erling, and Per-Anders Hillgren. 2004. On the Spot Experiments within Healthcare. In Proceedings of the Eighth Participatory Design Conference, Toronto.

Björgvinsson, Erling, Pelle Ehn, and Per-Anders Hillgren. 2010. Participatory Design and "Democratizing Innovation." In Proceedings of the Eleventh Participatory Design Conference, Sydney.

Blyth, Simon, and Lucy Kimbell. 2011. Design Thinking and the Big Society: From Solving Personal Troubles to Designing Social Problems. Actant and Taylor Haig.

Bristol, Katharine G. 1991. The Pruitt-Igoe Myth. Journal of Architectural Education 44 (3): 163-171.

Brown, Tim, and Jocelyn Wyatt. 2010. Design Thinking for Social Innovation (http://www .ssireview.org/articles/entry/design_thinking_for_social_innovation/).

Burns, Colin, Hilary Cottam, Chris Vanstone, and Jennie Winhall. 2006. Transformation Design (http://www.designcouncil.info/mt/RED/transformationdesign/).

Chesbrough, Henry. 2003. Open Innovation: The New Imperative for Creating And Profiting from Technology. Harvard Business School Press.

Coote, Anna. 2010. Cutting It: The "Big Society" and the New Austerity (http://s.bsd.net/ nefoundation/default/page/-/files/Cutting_it.pdf).

Cottam, Hilary. 2008. Beveridge 4.0 (http://www.participle.net/about/our_mission).

Cottam, Hilary. 2009. On the Big Society (http://www.participle.net/particles/P10/).

den Ouden, Elke, and Rianne Valkenburg. 2011. Balancing Value in Networked Social Innovation. In proceedings of Participatory Innovation Conference, University of Southern Denmark.

Design Council. 2004. RED Is a "Do Tank" That Develops New Thinking and Practice on Social and Economic Problems through Design-Led Innovation (http://www.designcouncil.info/mt/ RED/about/). 
Design Council. 2008. Design Council Briefing 02: The Role of Design in Public Services (http:// www.designcouncil.org.uk/Documents/Documents/Publications/Research/Briefings/ DesignCouncilBriefing02_TheRoleOfDesignInPublicServices.pdf).

Design Council. 2012a. Public Services by Design (http://www.designcouncil.org.uk/our-work/ leadership/).

Design Council. 2012b. Co-designing Ways to Improve How We Live, Work AND Play (http:// www.designcouncil.org.uk/our-work/challenges/Communities/Dott-Cornwall1/).

DESIS. 2012. DESIS Network (http://www.desis-network.org).

DESIS Lab. 2012. Amplifying Creative Communities (http://amplifyingcreativecommunities.net).

DiSalvo, Carl. 2010. Design, Democracy and Agonistic Pluralism. In proceedings of 2010 conference of Design Research Society, Montreal (http://www.designresearchsociety.org/docs-procs/ DRS2010/PDF/031.pdf).

Ehn, Pelle. 2008. Participation in Design Things. In Proceedings of the Tenth Anniversary Conference on Participatory Design, Indianapolis.

Engine. 2012. Building a Social Innovation Lab to Develop Services (http://enginegroup.co.uk/ work/kcc-social-innovation-lab).

European Commission. 2010. Europe 2020 (http://ec.europa.eu).

Hillgren, Per-Anders, Anna Seravalli, and Anders Emilson. 2011. Prototyping and Infrastructuring in Design for Social Innovation. CoDesign 7 (3-4): 169-183.

Howaldt, Jürgen, and Michael Schwarz. M. 2010. Social Innovation: Concepts, Research Fields AND International Trends, (http://www.sfs-dortmund.de/odb/Repository/Publication/ Doc\%5C1289\%5CIMO_Trendstudie_Howaldt_Schwarz_englische_Version.pdf).

Hubert, Agnès. 2011. Empowering People, Driving Change: Social Innovation in the European Union. Bureau of European Policy Advisers, European Commission.

Jégou, François, and Ezio Manzini, eds. 2008. Collaborative Services: Social Innovation and Design for Sustainability. POLI.design.

Jégou, François, Stéphane Vincent, Romain Thévenet, and Anna Lochard. 2013. Friendly Hacking into the Public Sector: Co-Creating Public Policies within Regional Governments. Presented at Boundary-Crossing Conference on Co-Design in Innovation, Aalto University (http://www .slideshare.net/27eregion/friendly-hacking-into-public-sector).

Kimbell, Lucy. 2011. Why I'm Joining the Young Foundation as Head of Social Design (http:// www.youngfoundation.org/blog/social-innovation/why-im-joining-young-foundation-head -social-design).

Leadbeater, Charles. 2008. We-Think: Mass Innovation, Not Mass Production. Profile Books.

Leadbeater, Charles. 2009. The Art of With (http://www.charlesleadbeater.net). 
Live Work. 2012. Sunderland: Make It Work (http://livework.co.uk).

Margolin, Victor, and Sylvia Margolin. 2002. A "Social Model" of Design: Issues of Practice and Research. Design Issues 18 (4): 24-30.

Mjölkdroppen. 2013. Mjölkdroppen—barnavårdscentralernas föregångare (http://www .mjolkdroppen.se).

Mulgan, Geoff. 2009. Strengths, Weaknesses and a Way Forward? (The original blog post at Social Innovation Exchange is gone, but the text can be found at http://blogs.lse.ac.uk.)

Mulgan, Geoff. 2012a. The Theoretical Foundations of Social Innovation. In Social innovation: Blurring Boundaries to Reconfigure Markets, ed. A. Nicholls and A. Murdock. Palgrave Macmillan.

Mulgan, Geoff. 2012b. Better by Design (http://www.nesta.org.uk).

Murray, Robin, Julie Caulier-Grice, and Geoff Mulgan. 2010. The Open Book of Social Innovation. Young Foundation and Nesta.

Nicholls, Alex, and Alex Murdock, eds. 2012. Social Innovation: Blurring Boundaries to Reconfigure Markets. Palgrave Macmillan.

Phills, James, A., Kriss Deiglmeier, and Dale T. Miller. 2008. Rediscovering Social Innovation. Stanford Social Innovation Review 6 (4) (http://www.ssireview.org/articles/entry/rediscovering _social_innovation).

Project H Design. 2012. Project H Design (http://projecthdesign.org/).

Robertson, Toni, and Jesper Simonsen. 2012. Challenges and Opportunities in Contemporary Participatory Design. Design Issues 28 (3): 3-9.

Rockefeller Foundation. 2008. Design for Social Impact: Workshop (http://www.rockefellerfoundation .org/uploads/files/50371640-262f-415e-ae01-09c60bdd60dc-socialimpact.pdf).

Schulman, Sarah. 2012. Ethical Outrage (http://www.inwithfor.org/2012/04/ ethical-outrage/\#start).

SEP. 2012. Sustainable Everyday Project-Research (http://www.sustainable-everyday.net/ main/?page_id=8).

SICP. 2012. About SICP-The Community Solutions Agenda (http://www.whitehouse.gov/ administration/eop/sicp/about).

Staszowski, Eduardo, Scott Brown, and Benjamin Winter. 2013. Reflections on Designing for Social Innovation in the Public Sector: A Case Study in New York City. In Public and Collaborative, ed. E. Manzini and E. Staszowski. DESIS Network.

Stigendal, Mikael, and Per-Olof Östergren. 2013. Malmös väg mot en hållbar framtid. Hälsa, Välfärd och rättvisa. Kommision för ett socialt hållbart Malmö, Malmö stad.

Think Public. 2012. Youcankingston (http://thinkpublic.com/case-studies/youcankingston/). 
Tonkinwise, Cameron. 2010. Politics Please, We're Social Designers (http://www.core77.com/ blog/featured_items/politics_please_were_social_designers_by_cameron_tonkinwise_17284.asp).

Westley, Frances, and Nino Antadze. 2010. Making a Difference: Strategies for Scaling Social Innovation for Greater Impact. The Innovation Journal 15 (2): 3-20. 